HUNGARIAN AGRICULTURAL ENGINEERING

$N^{\circ} 26 / 2014$ 39-46

Published online: http://hae-journals.org/

HU ISSN 0864-7410 (Print) / HU ISSN 2415-9751(Online)

DOI: 10.17676/HAE.2014.26.39
PERIODICAL OF THE COMITTEE OF AGRICULTURAL AND BIOSYSTEM ENGINEERING OF THE HUNGARIAN ACADEMY OF SCIENCES and SZENT ISTVÁN UNIVERSITY

Faculty of Mechanical Engineering

\title{
TECHNOLOGICAL FEATURES OF BIOGAS PLANTS USING MIXED MATERIALS
}

Author(s):

L. Tóth, J.Beke, Z. Bártfai, I. Szabó, G. Hartdégen, I. Oldal, Z. Blahunka

\section{Affiliation:}

Szent Isván University, Hungary, Gödöllő, 2100 Páter K. u. 1.

\section{Email address:}

toth.laszlo@gek.szie.hu, beke.janos@gek.szie.hu, bartfai.zoltan@gek.szie.hu, szabo.istvan@gek.szie.hu, oldal.istvan@gek.szie.hu, blahunka.zoltan@gek.szie.hu

\begin{abstract}
The most ecological and environmentally sensible way of the utilisation of biomass is the biogas production. The applied technologies are basically mesophile and thermophile methods, or the mixture of them. The applicable, effective energy production technology for biomass always depends on the input materials. Incineration is a wide-spread technology, mainly for the primer biomass. Fermentation is applied for those of secondary and tertiary materials that need post-treatment. Lot of materials need some kind of post treatment because of the environmental requirements (infection, ground water damage etc). Materials utilised for biogas production are no harmful for the environment, moreover the residues can be used as nutrient in the plant production technologies.
\end{abstract}

\section{Key words}

biogas, sewage sludge, fermentation, foam formation

\section{Introduction}

Biogas plants use a wide variety of primer materials such as whole corn silage, root crops, seed crops residues etc. that make the operation of the biogas plant more stabile as their structure is mainly constant in time. A biogas plant is quite similar to a ruminant animal. For example in the feeding of cows the so called TMR (TOTAL MIXED RATIO) system is used, that means the same composition of the feeds are used during the whole season. The stomach flora adapt to the feed and able to transform rapidly the desired quantity.

The biogas plant we studied within the frame of our research project applies different kind of input materials as a mixture. The mixing ratio also differs from the usual. In agricultural circumstances biomass is used as primer and waste from animal husbandry as sounder material is used for biogas production. When the composition of the materials is almost constant, and the material supply is continuous the operation of the biogas plant is acceptable.

The other kind of technology is based on fermentation of sewage sludge from waste water plants. The constitution of the input material is also constant, but max $10 \%$ deviation can be accepted.

In the examined technology the ratio of the sewage sludge is $55-60 \%$ (respect to the dry mat-ter). The sewage sludge as an input material comes from 8-10 settlements and the consignments differ very much from each other. $10 \%$ of the total amount of input materials is waste from food industry.

Having an up-to-date computer based control system, the electric power production of the biogas plant is approximately 2,0 MW (see Figure 1.)

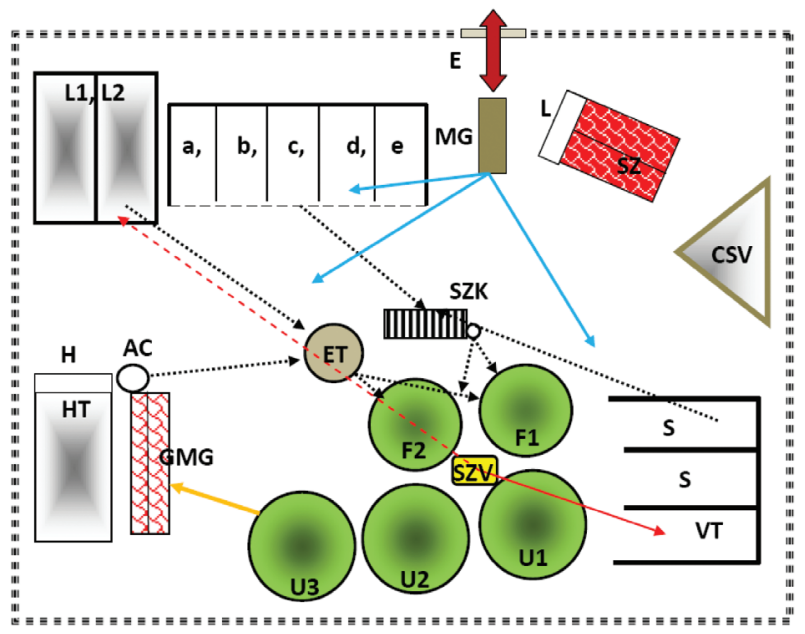

Figure 1. Scheme of the biogas plant 


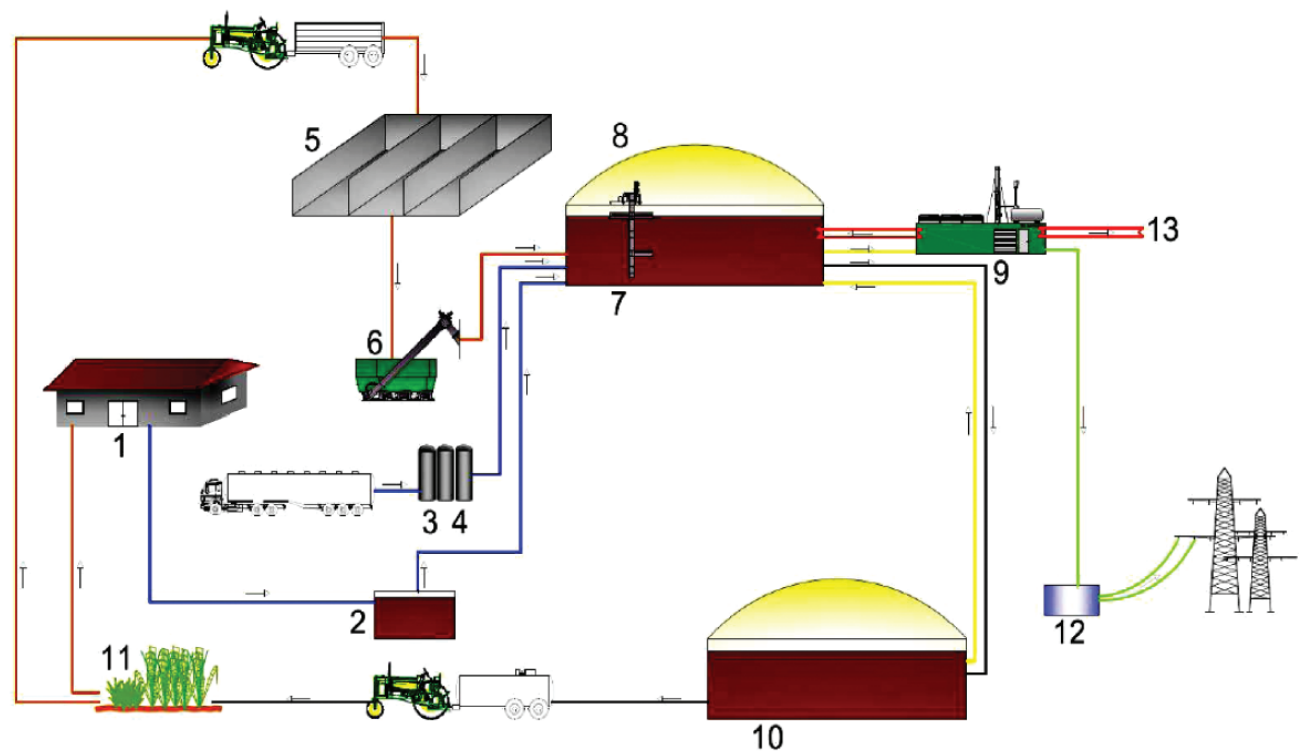

Figure 2. Biogas plant using mixed materials (Lemwig, Denmark)

1-manure, 2-liquid manure storage, 3-bio-waste storage, 4-autoclave, 5-solid matter storage, 6-chopping and feeding of solid matter, 7-biogas reactor, 8-biogas storage, 9-CHP unit, 10-substrate storage, 11-transport to field, 12-electrical transformer,

13- heat transport

According to their measurements the communities of bacteria don't have effect on foaming, meaning the indifference of the filamentous bacteria to the foam formation in the co-substrate based reactor. At the same time they confirm that filamentous bacteria, especially Gordonia species and Microthrix parvicella facilitate foaming in sewage sludge fermentation technolo-gies.

Their articles emphasize the organic overloading and subsequently the accumulation of acetic acid as the cause of foam formation in wastewater sludge digesters (corresponding to Boe at al.).

Moreno-Andrade et al. (2004) performed a research with $10 \%$ starting value of sewage sludge that was increased continuously for 30 days. During the start up of the plant the sewage sludge was recirculated, and the $\mathrm{pH}$ value was set-up by lime.

According to McCarty the sewage sludge as a substrate containes all the necessary nutrients for the bacteria. $60-75 \%$ of the dry content of sewage sludge is organic material. In the mesophilic range 12-13 days are needed for the decomposition of the sewage sludge having $70 \%$ organic mater content. Under $50 \%$ of organic matter content the anaerobic decomposition is not economic.

Oláh et al. emphasize that direct charging of the organic matter into the reactor can cause the overload. In this case intensive foaming may occour within 30 minutes and the methane con-tent of the biogas decrese as well.

The most important factors of foaming and solutions (based on literature):

- Composition of the organic matter should be constant, that helps to develop a well-balanced microbiological population (max. $4 \mathrm{~kg} /$ day $/ \mathrm{m} 3$ dry material).

- The best value of the $\mathrm{C} / \mathrm{N}$ ratio is $15-30 / 1$. When the level of nitrogen is low the carbon elaboration decreases-, while too much nitrogen reduces the methane production.

-Methane-producing bacteria live best under neutral to slightly alkaline conditions. Un-der anaerobic conditions, the $\mathrm{pH}$ will normally take on a value of between 7 and 7.5 (less then 6,8 can be harmful). In the presence of fermentative anaerobic organisms the optimal $\mathrm{pH}$ value is 4,5-6,3.

- The optimal dry matter content is $6-15 \%$ in the case of mechanical mixing. Continuous mixing is needed in order to maintain process stability and improving the efficiency within the digester.

-Fluctuation of the temperature reduces the methane development.

- Optimal temperature of the mesophilic bacteria is $35-40{ }^{\circ} \mathrm{C}$.

-Dry matter content determines the load of the reactor. Quantity and the concentration together give the correct information.

- Volatile acids, the HCO3 alkalinity and the ammonium concentration must be deter-mined.

- Volatile acid concentration is less than $1000 \mathrm{mg}$ acetic acid/1 equivalent

-FOS/TAC value: 03-04 is good, but depends on the system. $0,2-0,3$ is good in the sec-ond digester and the lagoon. When the value is less than 0,2 there is a lack of organic matter. Above 0,4 the organic matter content is too much.

- Air intake is needed for hydrogen sulphide oxidation (admissible content is 2-2,5\% of the gas)

Applied materials for producing biogas in the investigated plant:

- corn silage

- cow manure

- liquid manure

- sewage sludge (from 12 waste water plants)

- food residues

- oil-, and fat sludge

- expired food ( cold cuts, ice cream, chips)

The most important factors affecting the anaerob digestion:

-fresh inoculums

- constitution and concentration of the input material

- solids retention time, and the system load by the organic matter

-temperature, mixing and flowing compliance

- exclusion of toxic matter

In order to keep the desired efficiency, controlling some of the above mentioned factors (load, temperature, mixing) the operator is able to intervene, but changing the features of the sub-strate (chemical, microbiological constitution, toxix components) is complicated or sometimes impossible.

Discovering the real problem in the investigated plant, as a first step the constitution of the input material was examined with a 
special focus on energy and ash content. At the beginning of the research project we established a target: preparing recepients to create optimal inputs for the reactors.

Determining parameters are:

$-\mathrm{C} / \mathrm{N}$

- FOS/TAC
$-\mathrm{pH}$

Components are introduced in Chart 1. Components are signed Je. The desired ratio can be reached by changing the ratio of the components considering the reactor dry matter (SZA) capacity, and the load (SZA/kg).

Chart 1. Calculating table for the appropriate components ratio

\begin{tabular}{|c|c|c|c|c|c|c|c|c|c|}
\hline Matter/ & Dimension & & & & & & tc.. & $\Sigma_{\text {inp. }}$ & $\Sigma \mathbf{J e}_{\text {inp. }}$ \\
\hline & & $\mathrm{kg}$ & $\mathrm{Je}^{*}$ & $\mathrm{~kg}$ & $\mathrm{Je}^{*}$ & $\mathrm{~kg}$ & $\mathrm{Je}^{*}$ & $\mathrm{~kg}$ & Je (desired) \\
\hline $\mathrm{C} / \mathrm{N}$ & ratio & & & & & & & & $15-25$ \\
\hline SZA & $(\%)$ & & & & & & & & $8-12$ \\
\hline $\mathrm{pH}$ & & & & & & & & & $6,5-7,8$ \\
\hline $\mathrm{TAC} \mathrm{CaCO}_{3}$ & $(\mathrm{mg} / \mathrm{l})$ & & & & & & & & 13000 \\
\hline $\begin{array}{l}\text { FOS acetic } \\
\text { acid equiva- } \\
\text { lent }\end{array}$ & $(\mathrm{mg} / \mathrm{l})$ & & & & & & & & 3000 \\
\hline FOS/TAC & ratio & & & & & & & & $2,1-3,0$ \\
\hline KOI & $(\mathrm{mg} / \mathrm{l})$ & & & & & & & & 3000 \\
\hline $\mathrm{NH}_{3}-\mathrm{N}$ & $(\mathrm{mg} / \mathrm{l})$ & & & & & & & & 1600 \\
\hline Phosphate & $(\mathrm{mg} / \mathrm{l})$ & & & & & & & & $10,5-12$ \\
\hline
\end{tabular}

Calculating example:

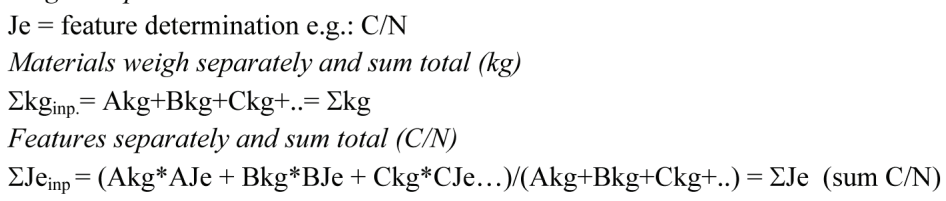

Calculation must be fulfilled for all the used input materials everytime, when feeding the reac-tor and always if any changes occour.

\section{Discussion}

Results of energetic and chemical tests of 3-3 samples (chosen from all the 12 input materials coming from different waste water plants) can be studied on figures 3-8. Dry matter content of the samples differs very much, but the $\mathrm{C}$ content is almost the same.
Significant difference can be found in the $\mathrm{pH}$ value and the $\mathrm{C} / \mathrm{N}$ ratio of the samples. It is a big problem and intervention needed to make a beter balance.

Although most of the samples show similar C content, the energy content differs very much. According to our results the higher the energy-, the lower the ash content, which means samples have a significant mineral contant (maybe because the malfunction of the sand separator). This is undesirable because the sand content increases the dry material content and block the gas flowing. Figure 5. shows this resul on two samples.

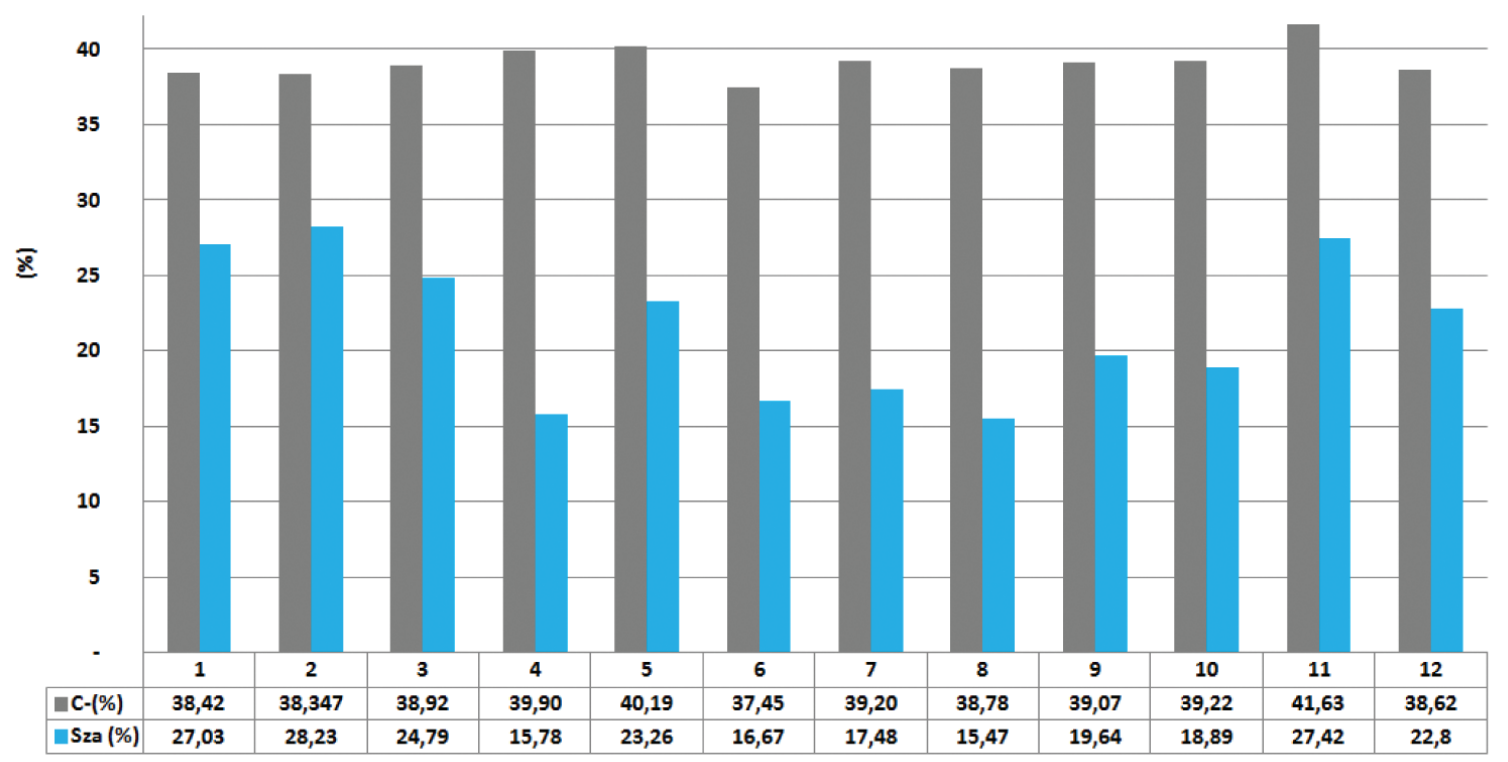

Figure 3. Dry matter content of the samples 


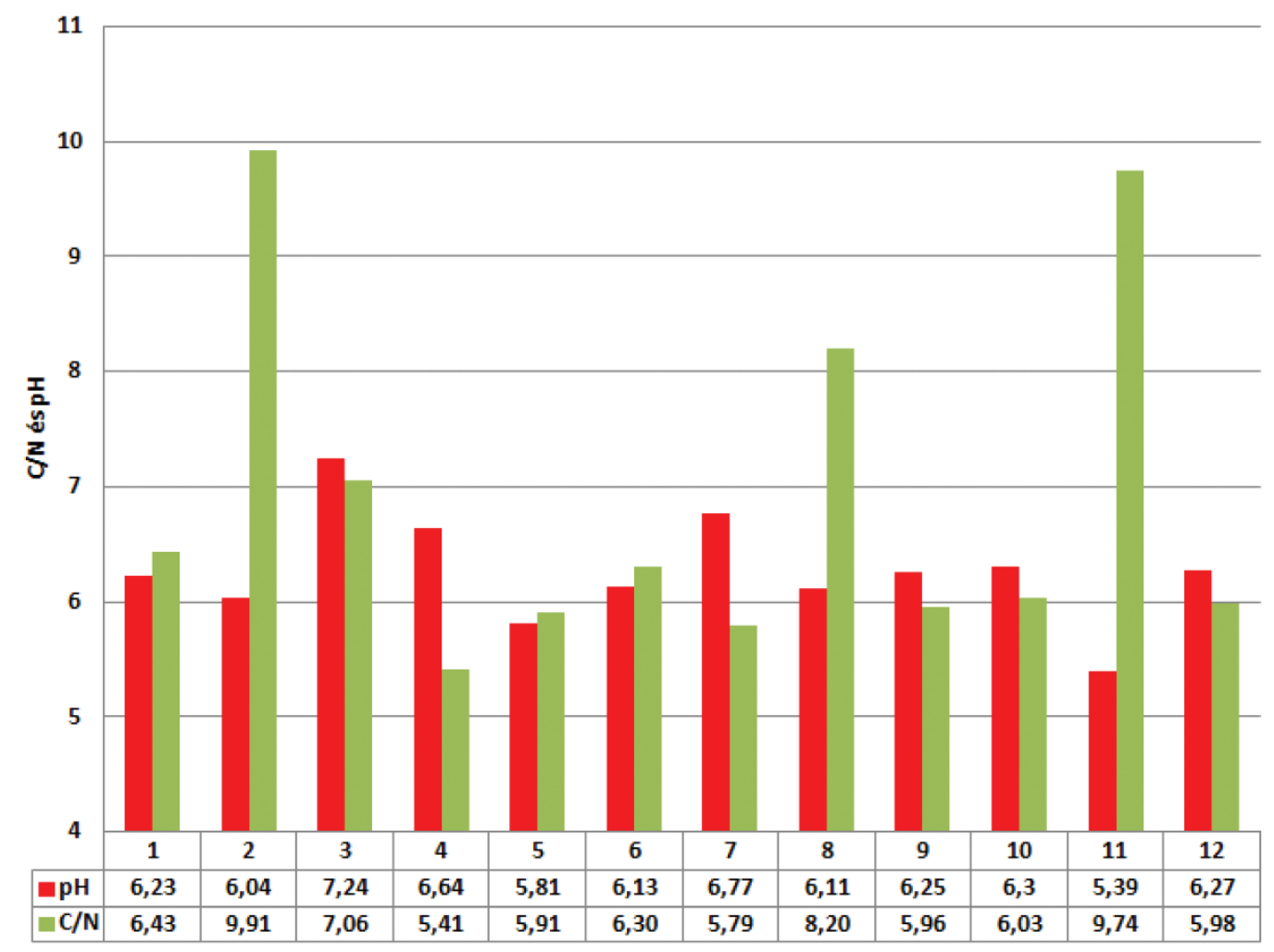

Figure 4. $\mathrm{pH}$ value and $\mathrm{C} / \mathrm{N}$ ratio (average)

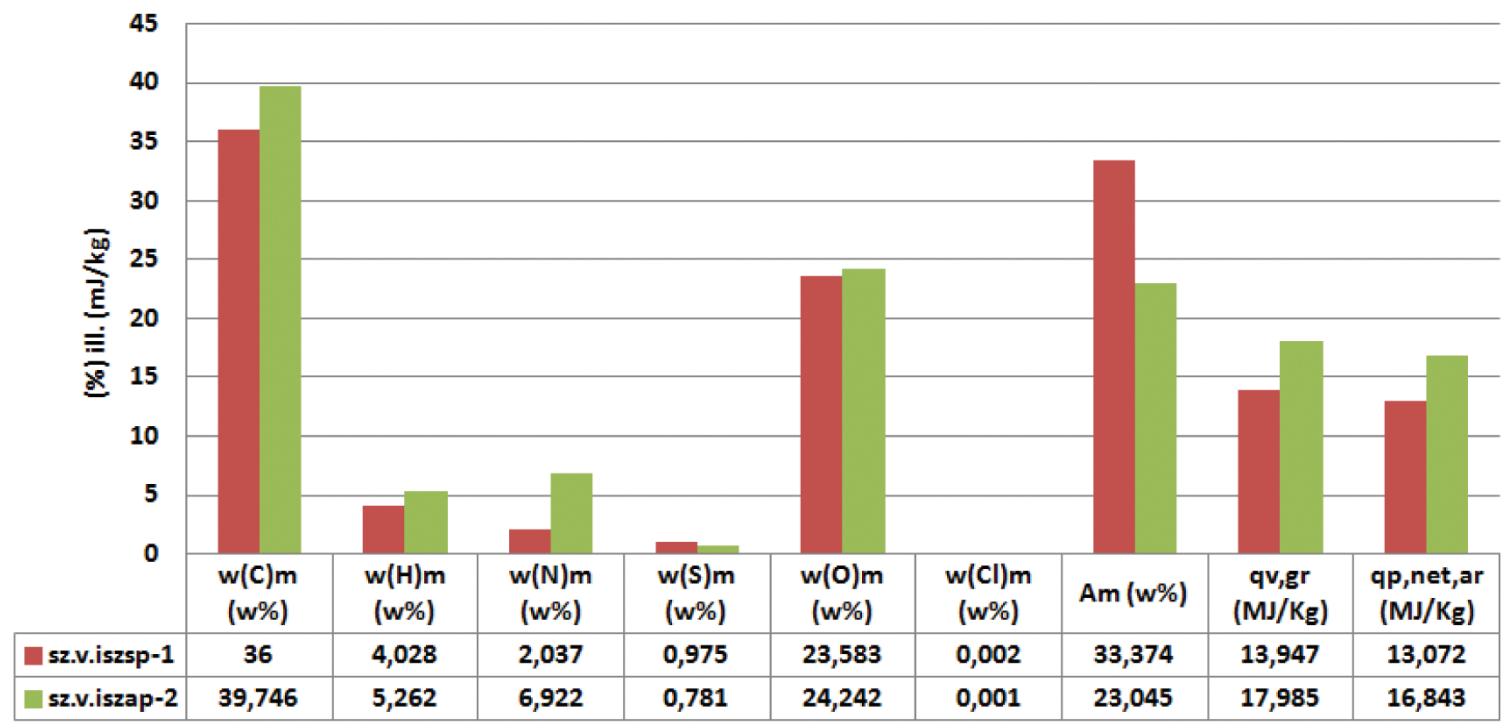

Figure 5. Constitution of two sewage sludge

\section{Meaning of the symbols}

$\mathrm{C}-, \mathrm{H}-, \mathrm{N}-, \mathrm{S}-, \mathrm{O}-, \mathrm{Cl}$ content

$\mathrm{A}_{\mathrm{m}}$ - ash content (wet weight basis)

$\mathrm{q}_{\mathrm{v}, \mathrm{gr}}-$ calorific value (wet weight basis)

$\mathrm{q}_{\mathrm{p} \text {,net,ar }}$ - calc. calor. value (wet weight basis)

$(\%)$

$(\mathrm{MJ} / \mathrm{kg})$

$(\mathrm{MJ} / \mathrm{kg})$

During the fermentation process $\mathrm{C}$ and the dry matter content decreases in the reactors. Com-pensation of the difference in the $\mathrm{C} / \mathrm{N}$ ratio was carried out by manure and corn silage dosage. Because of the F2 digester operated using more sewage sludge, the dry matter content and the $\mathrm{C} / \mathrm{N}$ ratio was disadvantageous, and the foaming was more intensive there.

Features of the corn silage (brown column) and the manure (green column) can be studied in figure 7. The energy contents are almost same, but the ash content of the manure is approx. 6 times higher (because of the sand content of the manure).

Features of the other input materials were also tested. Significant differenc was detected in the dry matter content, but they have more advantageous $\mathrm{C} / \mathrm{N}$ ratio than the sewage sludge. 


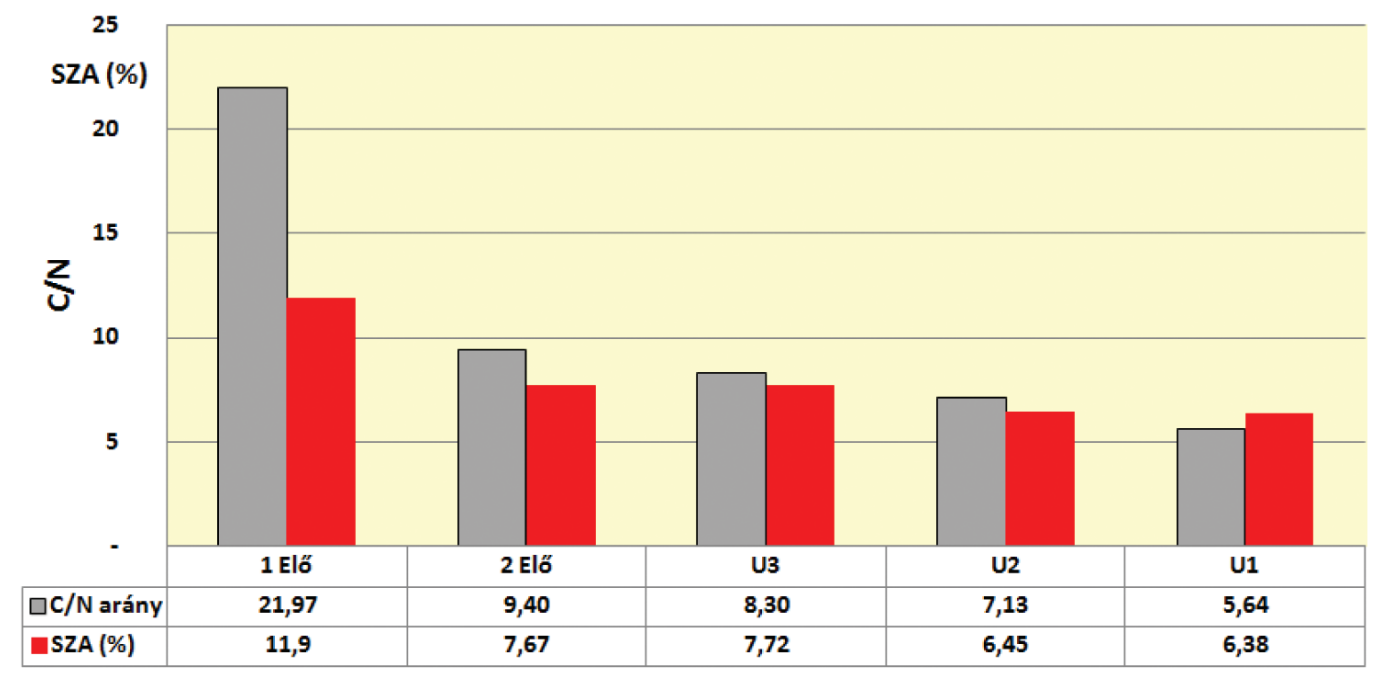

Figure 6. Changing the $\mathrm{C} / \mathrm{N}$ ratio and the dry matter content in the reactors

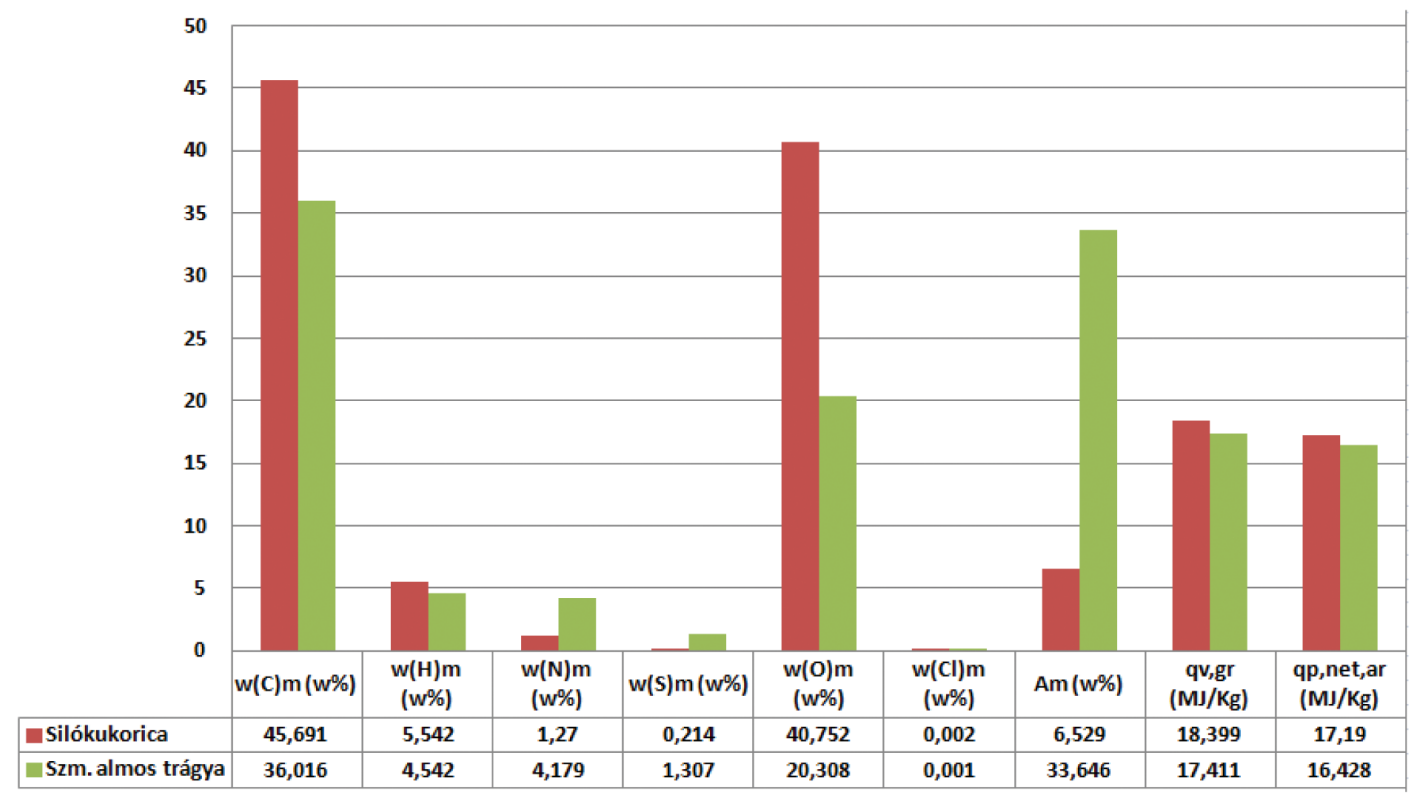

Figure 7. Features of the solids

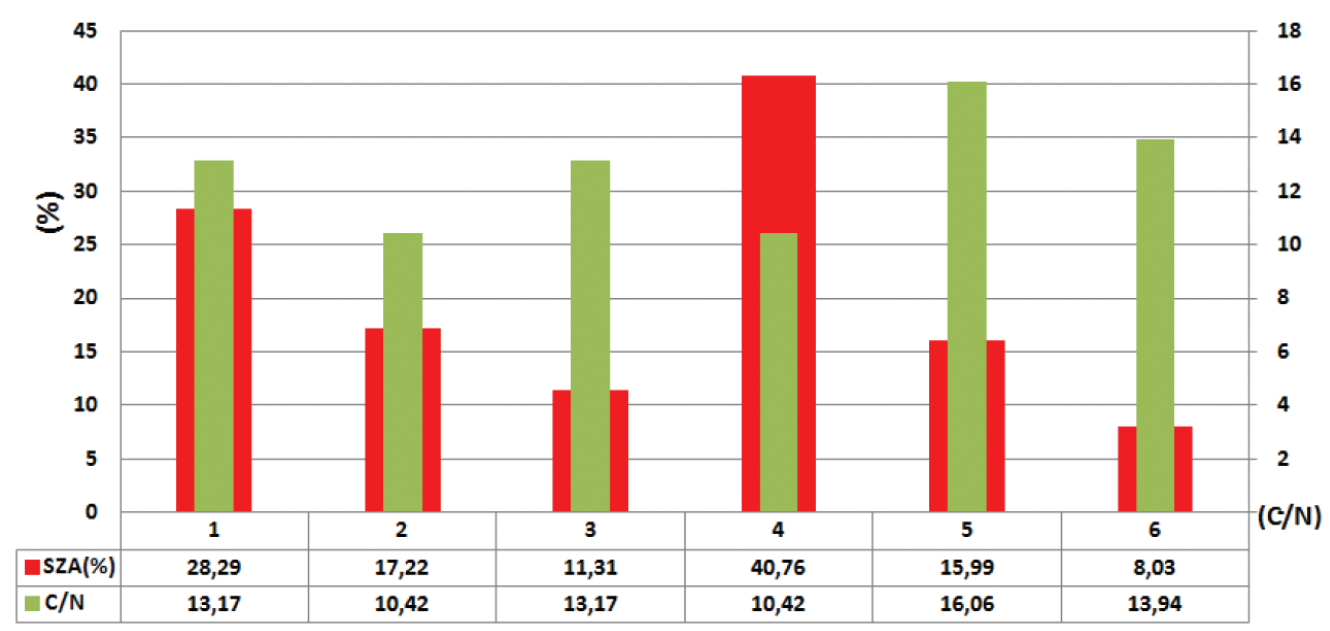

Figure 8. Features of the other materials

1) food residues, 2) liquid manure, 3) oil-, and fat sludge, 4) manure,

5) expired food ( cold cuts, ice cream, chips), 6) cooked oil. 
Feeding of the reactors can be realised from difrent sources, as the pre-storage bunker (ET), chopper (SZK) and the autoclave (AC) (see Figure 1.). All the reactors can be supplied by the central pump from all the mentioned sources. This can be important in the case of foaming.

\section{Utilisation of the end product}

With the help of the pump the substrate can flow from the second digesters to the separator, from where the liquid phase flows to the lagoon, and the solid phase goes to the concrete bun-kers (VT).

Some quantity of the solid residues -as have a high energy content- can be re-used in the fer-mentor in order to increase the $\mathrm{C}$ content. The dry end product can be used as nutrient on the fields or can be composted. Also some quantity of the liquid from the lagoon can be used to help for pre-mixing (in order to control the dry content).

According to the current regulations the liquid end product (digestate) must be handled as liquid manure and may be spread out to the fields only one time a year. It must be ploughed into the soil. Problems of this procedure are:
- plants are not able to utilise the so much quantity - sometimes nutrients are not available when plants need

The high moisture content is an advantage of spreading the liquid end product, and it can help amlot in dought. Other economical advantages can also be mentioned as digestate may substi-tute fertilisers, can be used well on sand soil $(0,5$ $0,7 \mathrm{GWh} /$ year electric capacity ensure diges-tate for 1,0-1,2 ha ploughland).

\section{Effect of the sewage sludge and the sand content of the manure}

Sewage sludge and manure contain significant quantity of sand (quartz sand). As the parti-cules are abrasive very much, the sand content is disadvantageous for the technical equip-ments (mainly for the chopper, and mixers). Sand stays at the bottom of the lagoon. This must be considered when using the digestate as diluent. Only precipitated digestate can be used for dilution!

The intensive abrasion makes serious problem in the chopper operation (figure 9.). Hammers wore rapidly, that cause inappropriate chopping. Fibrous material reduces the mixing efficien-cy that couses less gas production.

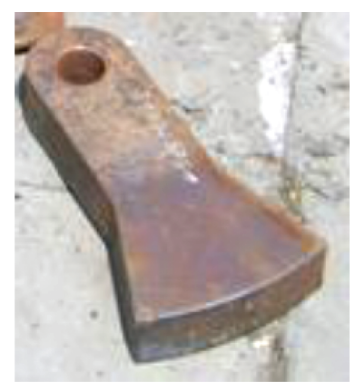

A

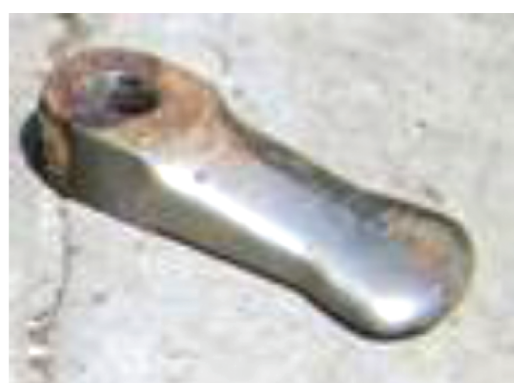

B

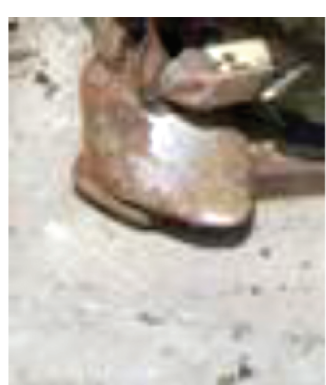

C

Figure 9. Abrasion of the hammers

A-original hammer, B-one month operated hammer, C-two months operated hammer

Strenghten of the edges (e.g. welding using hard metal) is suggested to avoide the intensive abrasion of the hammers.

\section{Effect of the mixers}

The digesters (F1, F2) have three same sized moveable mixers, and a bigger fix mixer. The second digesters (U1, U2, U3) have three, same sized moveable mixers. The vertical position of the smaller mixers can be changed, and they can be turned with 60 degrees from left to right.

Mixers play an important role in homogenisation. Optimal streamline inside the reactors sup-ports the adequate heat exchange for the heating pipeline that is needed for ensuring the ho-mogene reactor temperature. According to our monitoring the mixing process is inappropriate. Finding the optimal adjustment of the mixers modelling and simulation of the mixing process was performed. 135 variations were analysed. In a next article, we report on the modeling of mixing.

\section{Results}

During the 5 months research project our effort oriented to find the optimal feeding of the reactors. Ad hoc breakdowns of the system and sometimes stoppages of the needed input material supply resulted unwanted delays.
Application of the simulation resulted moderated foaming, and the number of the malfunc-tions of the system reduced. The specific gas prodaction, relative to the input material in-creased (see Chart 2.). During three months the electric capacity value grown from $61,2 \%$ to $68,7 \%$.

This proves our targets and the benefits of the research work, that would be sensible to con-tinue in order to optimise the applied technology.

\section{Summary}

This article dealt with an operational segment of a biogas plant. As far as we can prognosticate biogas plants will be wide spread in the near future in Hungary as the concept is supported by the Government. Furthermore the concept of settling biogas plants near by wastewater treatment plants is supported by the European Union. Biogas plant can be established in the area of a wastewater treatment plant, but the idea of serving a biogas plant by at least 2-3 sewage treatment plants seems to be more effective and economic. Usually the most important problems derive from the great variety of the input materials and the very much difference in content of them. Foaming is maybe the most serious malfunction. Operation without any troublesome can be observed mainly where recipes are used in the technology based on laboratory tests, focusing all the critical parameters and features 
of the input materials. If feeding is consistent, then the specific gas production ( $\mathrm{m} 3 \mathrm{gas} / \mathrm{kg}$ input material) increases. In Hungary the annual sewage production is $500.000 \mathrm{t}$, and only $20 \%$ is utilised for biogas pro-duction. A significant amount is sent to landfills, although the anaerobic digestion is the best solution considering the ecological and economical aspect. The endproducts of the biogas plants are energy (electric and heat as well) and good quality manure that can be used well in the plant production technologies.

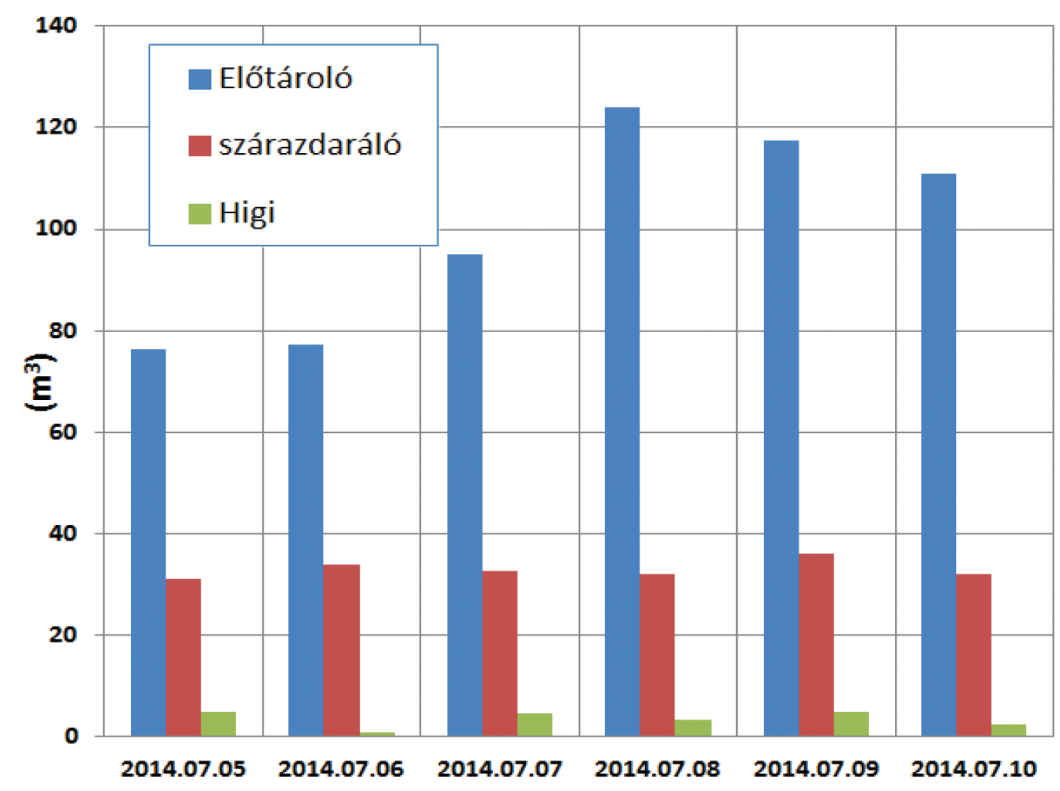

Figure 10. Fed materials

(blue-pre-storage, brown-solid chopper, green-autoclave)

Chart 2. Electric power capacity of the system

\begin{tabular}{|c|c|c|c|}
\hline $\begin{array}{c}\text { Rated capacity } \\
\text { MWh/month }\end{array}$ & $\begin{array}{c}\text { Effective ca- } \\
\text { pacity } \\
\text { (MWh/month) }\end{array}$ & $\begin{array}{c}\text { Calculated cap. from } \\
\text { inputs** } \\
\text { (MWh/month) }\end{array}$ & $\begin{array}{c}\text { Calculated cap. from } \\
\text { inputs * } \\
\text { MWh/month) }\end{array}$ \\
\hline 1480,56 & 592,2 & 1017,6 & 916,2 \\
\hline $100 \%$ & $40,0 \%$ & $68,7 \%$ & $61,2 \%$ \\
\hline
\end{tabular}

\section{References}

[1] A. Zehnsdorf, L. Moeller , K. Görsch, V. Beer. Bernburg, 2010 Schaumbildung in Biogasanlagen, Hemholtz, Zentrum für Umweltforschung UFZ, 30. November

[2] Bayerische Landesanstalt für Landwirtschaft (LfL). (2006). Biogastechnologie zur umweltverträglichen Flüssigmistverwertung und Energiegewinnung in Wasserschutzgebieten, (http://www.LfL.bayern.de/publikationen/)

[3] Esteves S- Miltner M-Fletch S: Folyamatos ellenőrzési útmutató a biogáz és biome-tán üzemek megfelelő müködtetéséhez

Gruber, W. (2007). Biogasanlagen in der Landwirtschaft. Aid infodienst Ver-braucherschultz, Ernährung, Landwirtschaft e.V. Bonn. 1453.

[4] Kardos L. A szennyvíztelepi biogáz termelő fermentációs folyamatok nyomon követése kémiai és biokémiai módszerekkel PhD dolgozat, ELTE, 2012

[5] Koppe, P. - Stozek, A. - Neitzel, V.: Municipal waste eater and sewage sludge in Rehm, H. J. and Reed G: Biotechnology, Volume. 11a. Environmental Process, p. 337-)
[6] Kougias P. G., Boe K., Thong S. O, Kristensen L. A. and Angelidaki I.: Anaerobic digestion foaming in full-scale biogas plants: a survey on causes and solutions ISWA publishing 2014, [7] Kovács at al (2003): A szennyviziszap-kezelés és hasznosítás jogi, gazdasági, müszaki, környezetegészségügyi feltételrendszere

http://www.emla.hu/alapitvany/02-03/szviszap.pdf

[8] Moreno-Andrade I., Buitron G. (2004): Influence of the origin of the inoculum on the anaerobic biodegradability test. Water Sci. and Technol. Vol. 49. No. 1.

[9] Noike T., Li Y.Y. (1989): State of the art on anaerobic bacteria for wastewater treatment. 2. Acid producing bacteria.

In: Study on Anaerobic Wastewater Treatment. Japan Society of Civil Enginers. To-kyo

[10] Oláh J- Palkó Gy- Szilágyi M- Barabás Gy- Gyarmati I- Tuba L: Rothasztók üzemeltetése http://statex.hu/cikkek/Uzemeles_szerkesztett 5 .pdf

[11] Öllős G-Oláh J-Palkó Gy: Rothasztás MAVÍZ, 2010

[12] Petis, M. (2008). Biogáz hasznosítása. Energiapolitika 2000 Társulat. Ener-giapolitikai Hétfö Esték. 2008.02.11. Budapest. 
[13] Tamás J, Blaskó L (2008) Environmental management, Debreceni Egyetem a TÁMOP 4.1.2 pályázat

[14] http://www.fvmmi.hu/file/document/hir/monitoringmagyar.pdf [15]

http://www.tankonyvtar.hu/hu/tartalom/tamop425/0032_kornyezett echnologia/ch06s11.html
[16]

http://www.researchgate.net/publication/260381931_Anaerobic_dig estion_foaming_in_full-scale_biogas_plants_a survey_on_causes and solutions 